\title{
SELECTED APPLICATIONS OF FLUORINATED MR CONTRAST AGENTS AND FLUORINE-CONTAINING DRUGS IN MEDICINE
}

\author{
DOROTA BARTUSIK-AEBISHER ${ }^{1 *}$, ZUZANNA BOBER $^{2}$ and DAVID AEBISHER ${ }^{2}$ \\ 'Department of Biochemistry and General Chemistry, \\ ${ }^{2}$ Department of Photomedicine and Physical Chemistry, \\ Medical College of University of Rzeszow, Rzeszow, Poland

\begin{abstract}
This review aims to present magnetic resonance imaging (MRI) and magnetic resonance spectroscopy (MRS) for applications in cellular therapeutics including descriptions of the use of ${ }^{19} \mathrm{~F}$ MRI and ${ }^{19} \mathrm{~F}$ MRS in drug tracking and visualization. Both MRI and MRS are often used as diagnostic tools in oncology, are non-invasive, and also can be employed for monitoring non-oncological and oncological therapies. Herein, we provide information pertaining to tracking and visualization of fluorinated drug uptake in cancer tissue in vitro, in vivo and ex vivo. The response of tissue to treatment is also discussed.
\end{abstract}

Keywords: ${ }^{19} \mathrm{~F}$ MRI, ${ }^{19} \mathrm{~F}$ MRS, drug design, drug delivery, drug efficacy

In general, drugs can selectively accumulate in tissue. Incorporation of NMR-detectable nuclei into drugs can improve monitoring of the therapeutic efficiency. In vitro Magnetic Resonance Imaging (MRI) and Magnetic Resonance Spectroscopy (MRS) are relatively novel methods as applied to pharmacology. The possibility of parallel application of both techniques on one sample makes its study easier and this approach is therefore commonly used (1). However, most applications of MRI and MRS in pharmacology involve in in vitro samples. To date, in vivo MRI or MRS has been successfully used in oncology, neurology, dermatology, gynecology, gastroenterology, urology, and many different areas of clinical medicine (2-5). The fast development of MRI and MRS techniques and the widespread availability of high-field magnets in the last decade has allowed for in vitro studies of tissues and cell cultures at higher magnetic field strength (6). This achievement is promising for in vitro drug testing. The most common parameter studied in MRI/MRS is NMR relaxation time. Two NMR relaxation times can be measured: (1) spin-lattice $\left(\mathrm{T}_{1}\right)$ and (2) spin-spin $\left(\mathrm{T}_{2}\right)$. Both, $\mathrm{T}_{1}$ and $\mathrm{T}_{2}$ magnetic relaxation times of water protons have been shown to be elevated for many types of tumors compared to normal tissues $(7,8)$. MRI methods used to study anticancer drug efficacy are also becoming one of the most important aspects of individual treatment protocols. Thus, noninvasive, repetitive measurements of efficacy parameters are attractive in the pre- and clinical context. MRI is an important non-surgical tool in medical and biomedical analysis. Although the most often used nucleus that produces an NMR signal is hydrogen ( $\left.{ }^{1} \mathrm{H} \mathrm{MRI}\right)$, there is also the possibility of imaging other nuclei such as fluorine ${ }^{19} \mathrm{~F}$, carbon ${ }^{13} \mathrm{C}$, phosphorus ${ }^{31} \mathrm{P},{ }^{15} \mathrm{~N}$, oxygen ${ }^{17} \mathrm{O}$ and sodium ${ }^{23} \mathrm{Na}$. Due to the fact that the most abundant nuclei in the human body is hydrogen and that the hydrogen nucleus the highest NMR signal of all nuclei, it is most often measured in the clinic.

\section{Fluorinated contrast agents}

Due to a similar resonance frequency, the fluorine nucleus is increasingly used in scientific work as a stand-alone contrast agent or in combination with other clinical contrast agents (Table 1) $(1,9)$. The relaxation agent gadolinium has been incorporated into perfluorocarbon (PFC) lipid monolayers for plasma clot visualization which has been reported to result in a fourfold increase in ${ }^{19} \mathrm{~F}$ relation rate at $1.5 \mathrm{~T}$ (10). The anticancer drug dexamethasone phosphate has also been encapsulated within PFC nanoparticles for visualization of delivery (11).

\footnotetext{
* Corresponding author: e-mail: dbartusik-aebisher@ur.edu.pl
} 
Perfluoro-15-crown-5-ether has also been used extensively for cell labeling and visualization by ${ }^{19} \mathrm{~F}$ MRI alone $(12,27)$, and in silicone-coated polychlorotrifluoroethylene capsules (13). Human neural stem cells (NSCs) have been labeled with perfluoropolyether (PFPE) for ${ }^{19} \mathrm{~F}$ MRI tracking in brain implantation studies (14). A decrease in $\mathrm{T}_{2}$ by ${ }^{19} \mathrm{~F}$ MRI in vessel thrombi in rats using superparamagnetic iron oxide (SPIO) in the presence of perfluoro15-crown-5-ether has also been demonstrated (15), and the combination of SPIO with ${ }^{19} \mathrm{~F}$ nanoemulsion has been used to monitor transplantation of mesenchymal stem cells (29).

${ }^{19} \mathrm{~F}$ MRI has been employed in the tracking of ${ }^{19} \mathrm{~F}$-labeled catheters and capsules in the gastrointestinal tract in vivo (16). Perfluorooctylbromide (PFOB) emulsion grafted with polyethylene glycol (PEG) has been used to perform liver and spleen measurements in vivo (17) and to detect angiogenesis (24). Emulsified perfluorocarbon has been extensively employed to label and track cells by ${ }^{19} \mathrm{~F}$ MRI $(18,23,40)$, to measure $\mathrm{pO}_{2}$ level in tissue $(19,21)$, for detecting sites of Staphylococcus aureus infection (20), and for production of 'hotspot' images of immunotherapeutic dendritic cells (DCs) in patients with colorectal adenocarcinoma $(25) .{ }^{19} \mathrm{~F}$ MRI is an excellent method for verification of therapeutic cell delivery (32, 39), histopathological analysis (31), and transplantation imaging (38). Furthermore, ${ }^{19} \mathrm{~F}$ MRI and ${ }^{19} \mathrm{~F}$ MRS have been used to identify specific cell types post in vitro and in-vivo ${ }^{19} \mathrm{~F}$-labeling $(28,33,37)$ including imaging macrophage burden in tumors (41).

In particular, in the study of various types of disease, both diagnostic and spectroscopic are studies have involved ${ }^{19} \mathrm{~F}$-labeled contrast agents. The introduction of ${ }^{19} \mathrm{~F}$ labeled contrast agents into cell culture offers a controlled and systematic way to image cellular and molecular properties associated with the disease progression. ${ }^{19} \mathrm{~F}$ MRI allows imaging without tissue background, which turns out to be extremely important in the case of research on pharmaceutical substances. MRI in vivo methods allows for simultaneous visualization of drug dosage and anatomical structures (42). Temperature activated liposomal fluorinated drug carriers have been developed in which location is determined by ${ }^{1} \mathrm{H}$ chemical exchange saturation transfer (CEST) and drug release by ${ }^{19} \mathrm{~F}$ MRI (43). Two different $\mathrm{T}_{2}$ relaxation times were found for fluorinated acrylate and methacrylate monomer micelles that may aid in diagnostic ${ }^{19} \mathrm{~F}$ MRI imaging (44), and supramolecular organic nanoparticles have been reported to detect specific proteins by ${ }^{19} \mathrm{~F}$ MRI (45). ${ }^{19} \mathrm{~F}$ MRI allows for quantification of cell numbers using fluorocarbons previously used as blood substitutes and imaging agents for ultrasound and computed tomography (46).

In studies of breast cancer treatment, Herceptin was delivered with perfluorooctyl bromide (PFOB) and conjugated with lipoplex, containing plasmid DNA and lipofectamine (LipA) allowing antibody imaging by ${ }^{19} \mathrm{~F}$ MRI. Treatments such as Herceptin, Herceptin/PFOB and Herceptin/PFOB/lipoplex were used for ex vivo targeting of MCF-7 cells cultured in three-dimensional (3D) geometry using a hollow fiber bioreactor (HFB) device (47). The efficacy of Herceptin, a common breast cancer drug conjugated with a fluorine organic compound, perfluoro-15-crown-5-ether (PFCE) easily forms biocompatible emulsions and was synthesized for an ex vivo study of their effectiveness in breast cancer treatment (48). Human monocytes and macrophages have been fluorinated with perfluoro-15-crown-5ether for ${ }^{19} \mathrm{~F}$ MRI detection of acute allograft rejection (49, 50). Magnetite-loaded fluorine-containing polymeric micelles have been suggested to be of clinical use in organ imaging and as drug delivery agents (51). Perfluoropolyether (PFPE) has been successfully used to label and track dendritic cells which will lead to further clinical trials in tracking therapeutic (52). Perfluorooctyl bromide nanocapsules have been synthesized for tumor imaging by ${ }^{19} \mathrm{~F}$ MRI (53). The combination of ${ }^{19} \mathrm{~F}$ and ${ }^{1} \mathrm{H}$ MRI allows for tracking of perfluorocarbon labeled stem and immune cells in experimental disease models after labeling with perfluorocarbon; the primary advantage is the unique signal in vivo due to the absence of background signal (54). The combination of fluorescence and ${ }^{19} \mathrm{~F}$ MRI has been demonstrated in fluorophore-labeled ${ }^{19} \mathrm{~F}$ nanoparticles for visualizing the development of encephalomyelitis (22). Multifunctional mesoporous silica nanoparticles (MSNs) have been employed in tracking drug delivery, bioimaging, and cell targeting and can be labeled with fluorescent dyes and functionalized with targeting drugs $(26,30,34,35)$. Fluorinated ligands also have medical applications in ${ }^{18} \mathrm{~F}$-labelled positron emission tomography (PET) (36).

\section{MRS and MRI of fluorinated drugs}

Magnetic resonance spectroscopy and Magnetic Resonance Imaging are non-invasive methods of studying fluorinated drug distribution in vivo. The occurrence of fluorine in several drugs coupled with favorable MR properties enables tracking of drug absorption, distribution, metabolism, and delivery (55). The use of fluorine in drug design 
Table $1 .{ }^{19} \mathrm{~F}$ fluorinated contrast agents.

\begin{tabular}{|c|c|c|}
\hline Reference & Type of contrast & Applications \\
\hline Neubauer et al. 2008 (10) & $\begin{array}{l}\text { Lipophilic gadolinium-diethylene-triamine-pentaacetic } \\
\text { acid-bisoleate }\end{array}$ & ${ }^{19} \mathrm{~F} \mathrm{MRI} / \mathrm{S}$ in vitro \\
\hline Zhou et al. 2009 (11) & Dexamethasone acetate-loaded perfluorocarbon nanoparticles & ${ }^{19} \mathrm{~F} \mathrm{MRI} / \mathrm{S}$ in vitro \\
\hline Kadayakkara et al. 2010 (12) & Perfluoro-15-crown-5-ether & ${ }^{19} \mathrm{~F} \mathrm{MRI} / \mathrm{S}$ in vivo \\
\hline Hahn et al. 2011 (13) & $\begin{array}{l}\text { Silicone coated polychlorotrifluoroethylene capsules filled } \\
\text { with perfluoro-15-crown-5-ether }\end{array}$ & ${ }^{19} \mathrm{~F} \mathrm{MRI} / \mathrm{S}$ in vivo \\
\hline Boehm-Sturm et al. 2011 (14) & Perfluoropolyether nano-emulsion & ${ }^{19} \mathrm{~F} \mathrm{MRI} / \mathrm{S}$ in vivo \\
\hline Weise et al. 2011 (15) & Perfluoro-15-crown-5-ether & ${ }^{19} \mathrm{~F} \mathrm{MRI} / \mathrm{S}$ in vivo \\
\hline Hahn et al. 2012 (16) & Perfluoro-15-crown-5-ether & ${ }^{19} \mathrm{~F} \mathrm{MRI} / \mathrm{S}$ in vivo \\
\hline Giraudeau et al. 2012 (17) & Perfluorooctyl bromide emulsion & $\begin{array}{l}{ }^{19} \mathrm{~F} \mathrm{MRI} / \mathrm{S} \text { in vivo / } \\
\text { in vitro }\end{array}$ \\
\hline Waiczies et al. 2013 (18) & Perfluoro-15-crown-5-ether & ${ }^{19} \mathrm{~F}$ MRS in vivo \\
\hline Shi et al. $2013\left({ }^{19}\right)$ & $\begin{array}{l}\text { Perfluoro-15-crown-5-ether mixed with an emulsifying } \\
\text { solution of lecithin soy and lactated Ringers solution }\end{array}$ & ${ }^{19} \mathrm{~F} \mathrm{MRI} / \mathrm{S}$ in vivo \\
\hline Hertlein et al. 2013 (20) & $\begin{array}{l}\text { Vancomycin and linezolid dissolved in sterile } 0.9 \% \mathrm{NaCl} \\
\text { solution; perfluoro-15-crown-5-ether }\end{array}$ & ${ }^{19} \mathrm{~F} \mathrm{MRI} / \mathrm{S}$ in vivo \\
\hline Zhong et al. 2013 (21) & Perfluoro-15-crown-5-ether & ${ }^{19} \mathrm{~F} \mathrm{MRI} / \mathrm{S}$ in vivo \\
\hline Waiczies et al. 2013 (22) & $\begin{array}{l}\text { Perfluoro-15-crown-5-ether and labeled them with a } \\
\text { fluorescent dye (DiI) prior }\end{array}$ & ${ }^{19} \mathrm{~F} \mathrm{MRI} / \mathrm{S}$ in vivo \\
\hline Patel et al. 2013 (23) & $\begin{array}{l}\text { Perfluorocarbon and perfluoro-tert-butyl ether, 1-((1,1,1,3, } \\
\text { 3,3-hexafluoro-2-(trifluoromethyl)propan-2-yl)oxy)octane }\end{array}$ & ${ }^{19} \mathrm{~F} \mathrm{MRI} / \mathrm{S}$ in vitro \\
\hline Giraudeau et al. 2013 (24) & Perfluorooctylbromide nanoparticles (PFOB NP) & ${ }^{19} \mathrm{~F} \mathrm{MRI} / \mathrm{S}$ in vivo \\
\hline Ahrens et al. 2014 (25) & Commercially available perfluorocarbon MRI tracer reagent & ${ }^{19} \mathrm{~F} \mathrm{MRI} / \mathrm{S}$ in vivo \\
\hline Matsushita et al. 2014 (26) & $\begin{array}{l}\text { Perfluoro-15-crown-5-ether and fluorine accumulated silica } \\
\text { nanoparticle for MRI enhancement }\end{array}$ & ${ }^{19} \mathrm{~F} \mathrm{MRI} / \mathrm{S}$ in vivo \\
\hline Jacoby et al. 2014 (27) & $\begin{array}{l}\text { Perfluorooctyl bromide, perfluorodecalin and trans-bis- } \\
\text { perfluorobutyl ethylene }\end{array}$ & ${ }^{19} \mathrm{~F} \mathrm{MRI} / \mathrm{S}$ in vivo \\
\hline Temme et al. 2014 (28) & Perfluoro-15-crown-5-ether & ${ }^{19} \mathrm{~F} \mathrm{MRI} / \mathrm{S}$ in vivo \\
\hline Muhammad et al. 2015 (29) & $\begin{array}{l}\text { Superparamagnetic iron oxide nanoparticles and phosphate- } \\
\text { buffered saline }\end{array}$ & ${ }^{19} \mathrm{~F} \mathrm{MRI} / \mathrm{S}$ in vitro \\
\hline Nakamura et al. 2015 (30) & $\begin{array}{l}\text { Fluorine accumulated silica nanoparticles for MRI } \\
\text { enhancement and perfluoro-15-crown-5-ether }\end{array}$ & ${ }^{19} \mathrm{~F} \mathrm{MRI}$ in vivo \\
\hline Zhong et al. 2015 (31) & $\begin{array}{l}\text { Perfluorocarbon nanoemulsion with a lipophilic } \\
\text { dialkylcarbocyanine }\end{array}$ & ${ }^{19} \mathrm{~F} \mathrm{MRI} / \mathrm{S}$ in vivo \\
\hline Gaudet et al. 2015 (32) & Red fluorescent perfluoropolyether agent, Cell Sense & ${ }^{19} \mathrm{~F} \mathrm{MRI} / \mathrm{S}$ in vivo \\
\hline Gonzales et al. $2016(33)$ & Perfluoropolyether perfluorocarbon polymer & ${ }^{19} \mathrm{~F} \mathrm{MRI} / \mathrm{S}$ in vivo \\
\hline Kenny et al. 2016 (34) & Tetraethyl((2,2,2-trifluoroacetamido) methylene)bisphosphonate & $\begin{array}{l}{ }^{19} \mathrm{~F} \mathrm{MRI} / \mathrm{S} \text { in vivo / } \\
\text { in vitro }\end{array}$ \\
\hline Taylor et al. $2016(35)$ & $\begin{array}{l}\text { 3,5bis(trifluoromethyl)-benzylamine; perfluoro-tert-butyl } \\
\text { alcohol; trifluoroacetic acid in distilled } \mathrm{H}_{2} \mathrm{O}\end{array}$ & ${ }^{19} \mathrm{~F} \mathrm{MRI} / \mathrm{S}$ in vivo \\
\hline Olaru et al. 2017 (36)] & $\begin{array}{l}\text { Ligands L1-L6; [Ir(IMes)(COD)L]+; (COD=cyclooctadiene; } \\
\text { IMes=1,3-bis(2,4,6-trimethylphenyl)imidazole-2-ylidene) }\end{array}$ & ${ }^{19} \mathrm{~F} \mathrm{MRI} / \mathrm{S}$ in vivo \\
\hline Constantinides et al. 2017 (37) & Perfluoro-15-crown-5-ether & ${ }^{19} \mathrm{~F} \mathrm{MRI}$ in vivo \\
\hline Liang et al. 2017 (38) & Perfluoro-15-crown-5-ether & ${ }^{19} \mathrm{~F} \mathrm{MRI} / \mathrm{S}$ in vivo \\
\hline Shin et al. 2017 (39) & $\begin{array}{l}\text { Lutrol F68, phosphate buffered saline and perfluoro- } \\
\text { 15-crown-5-ether }\end{array}$ & ${ }^{19} \mathrm{~F} \mathrm{MRI} / \mathrm{S}$ in vivo \\
\hline van Heeswijk et al. 2018 (40) & Perfluorooctyl bromide & ${ }^{19} \mathrm{~F} \mathrm{MRI} / \mathrm{S}$ in vivo \\
\hline Khurana et al. 2018 (41) & Perfluorocarbon & ${ }^{19} \mathrm{~F} \mathrm{MRI} / \mathrm{S}$ in vivo \\
\hline
\end{tabular}


Table 1. Continued.

\begin{tabular}{|c|c|c|}
\hline Reference & Type of contrast & Applications \\
\hline Christmann et al. 1997 (42) & $\begin{array}{l}\text { Oral contrast agents containing Gd-DTPA in fluorine-labelled } \\
\text { minicapsules }\end{array}$ & $\begin{array}{l}{ }^{19} \mathrm{~F} \text { MRI of the } \\
\text { digestive organs } \\
\text { in a rat model in } \\
\text { vivo }\end{array}$ \\
\hline Langereis et al. 2009 (43) & Liposomal fluorinated contrast agent & $\begin{array}{l}{ }^{19} \mathrm{~F} \mathrm{MRI} / \mathrm{S} \text { of drug } \\
\text { delivery }\end{array}$ \\
\hline Peng et al. 2009 (44) & Fluorinated acrylate and methacrylate monomers & $\begin{array}{l}{ }^{19} \mathrm{~F} \mathrm{MRI} / \mathrm{S} \text { of partly } \\
\text { fluorinated block } \\
\text { copolymers in vitro }\end{array}$ \\
\hline Takaoka et al. 2009 (45) & $\begin{array}{l}\text { Supramolecular organic nanoparticles to detect specific } \\
\text { proteins by }{ }^{19} \mathrm{~F} \text {-based MRI in an off/on mode }\end{array}$ & $\begin{array}{l}{ }^{19} \mathrm{~F} \text { MRI use to } \\
\text { visualize clearly the } \\
\text { protein within live } \\
\text { cells in vivo and } \\
\text { ex vivo }\end{array}$ \\
\hline Srinivas et al. $2010(46)$ & Fluorinated poly(D,L-lactide-co-glycolide & $\begin{array}{l}{ }^{19} \mathrm{~F} \mathrm{MRI} / \mathrm{S} \text { of pri } \\
\text { mary human den } \\
\text { dritic cells in vivo }\end{array}$ \\
\hline $\begin{array}{l}\text { Bartusik and Tomanek, } \\
2010 \text { (47) }\end{array}$ & $\begin{array}{l}\text { Herceptin was used with perfluorooctyl bromide (PFOB) } \\
\text { and conjugated with Lipoplex, containing plasmid DNA } \\
\text { and Lipofectamine }\end{array}$ & $\begin{array}{l}{ }^{19} \mathrm{~F} \mathrm{MRI} / \mathrm{S} \text { of breast } \\
\text { cancer cells in vitro }\end{array}$ \\
\hline $\begin{array}{l}\text { Bartusik and Tomanek, } \\
2010 \text { (48) }\end{array}$ & $\begin{array}{l}\text { Herceptin, with a fluorine organic compound, perfluoro- } \\
15 \text {-crown-5-ether }\end{array}$ & $\begin{array}{l}{ }^{19} \mathrm{~F} \mathrm{MRI} / \mathrm{S} \text { of breast } \\
\text { cancer cells in vitro }\end{array}$ \\
\hline Hitchens et al. 2011 (49) & $\begin{array}{l}\text { Human monocytes and macrophages fluorinated with } \\
\text { perfluoro-15-crown-5-ether }\end{array}$ & $\begin{array}{l}{ }^{19} \mathrm{~F} \text { MRI to cellular } \\
\text { tracer agent to } \\
\text { detect macrophage } \\
\text { accumulation in } \\
\text { rodent models } \\
\text { in vitro }\end{array}$ \\
\hline Bonetto et al. 2011 (50) & Human monocytes fluorinated with perfluoro-15-crown-5-ether & $\begin{array}{l}{ }^{19} \mathrm{~F} \text { MRI of primary } \\
\text { human monocyte- } \\
\text { derived dendritic } \\
\text { cells in mouse, } \\
\text { in vivo }\end{array}$ \\
\hline Li et al. $2012(51)$ & Magnetite-loaded fluorine-containing polymeric micelles & $\begin{array}{l}{ }^{19} \mathrm{~F} \mathrm{MRI} / \mathrm{S} \text { of a } \\
\text { mouse liver and } \\
\text { spleen }\end{array}$ \\
\hline Helfer et al. 2012 (52) & Alpha-type-1-polarized dendritic cell & $\begin{array}{l}{ }^{19} \mathrm{~F} \mathrm{MRI} / \mathrm{S} \text { of alpha- } \\
\text { type-1-polarized } \\
\text { dendritic cell traf } \\
\text { ficking in murine } \\
\text { models }\end{array}$ \\
\hline Diou et al. 2012 (53) & PLGA-PEG nanocapsules & $\begin{array}{l}{ }^{19} \mathrm{~F} \text { MRS for tumor } \\
\text { imaging }\end{array}$ \\
\hline Stoll et al. $2012(54)$ & Perfluorocarbon emulsions & $\begin{array}{l}{ }^{19} \mathrm{~F} \text { MRI of stem and } \\
\text { immune cells }\end{array}$ \\
\hline
\end{tabular}

is increasing since the introduction of fluorine into a molecule can alter solubility, $\mathrm{p} K_{\mathrm{a}}$, potency, and pharmacokinetic properties (56).

The anticancer drug 5-fluorouracil (5-FU) has been detected by ${ }^{19} \mathrm{~F}$ MRI in rats with Morris hepatoma (57), and 5-FU accumulation has been detected in human patients with carcinoma of the breast, colon, endometrium, cervix, and kidney (58).
The enzyme-mediated decomposition of the anticancer drug 5-fluorocytosine to 5-FU has been measured noninvasively in vitro and in vivo using ${ }^{19} \mathrm{~F}$ MRS in glioma cells (59). A fluorinated analog of methotrexate (MTX), 3'-fluoromethotrexate (FMTX), has been synthesized and measured by ${ }^{19} \mathrm{~F}$ MRI. 3'fluoromethotrexate was found to have an in vitro cytotoxicity equivalent to the parent compound, and 
tumor accumulation of the labeled compound in vivo was observed by ${ }^{19} \mathrm{~F}$ MRS in a human tumor xenograft model (60). Accumulation of the fluorinecontaining anticancer drug capecitabine has also been detected in human livers after oral administration by ${ }^{19} \mathrm{~F}$ MRS (61).

One of the earliest studies that demonstrated the ability to image neurological fluorinated drugs was reported by Arndt et al. where biodistribution of the antipsychotic drug fluphenazine was imaged at the site of injection and within brain tissue by ${ }^{19} \mathrm{~F}$ MRI (62). Several years later, quantitative pharmacokinetics and brain distributions of fluorine-containing antidepressants fluvoxamine and fluoxetine were reported (63). Elimination rates of fluvoxamine in the brain and plasma were later measured by ${ }^{19} \mathrm{~F}$ MRS (64). In neurological studies to evaluate the loss of dopaminergic neurons in Parkinson's disease, ${ }^{19} \mathrm{~F}$ MRI of fluorodopa (F-DOPA) was shown to be a promising probe for evaluating dopaminergic presynaptic function (65). The fluorinated antiinflammatory drug niflumic acid which acts as a prostaglandin synthase inhibitor was detected in the human liver, blood plasma, and urine by ${ }^{19} \mathrm{~F}$ MRS (66). The disappearance of topically applied flurbiprofen, a fluorinated anti-inflammatory drug, was also measured by ${ }^{19} \mathrm{~F}$ MRS (67). The concentration of the fluorinated anorectic drug dexfenfluramine
(DF) was quantitatively measured by ${ }^{19} \mathrm{~F}$ MRS and this demonstrated that fluorinated drugs can be quantified using ${ }^{19} \mathrm{~F}$ MRS at concentrations below 10 $\mu \mathrm{M}$ in the human brain (68).

The compound perfluorodecalin (PFD), which is extensively used in medicine due to its ability to dissolve oxygen, has also been reported to be detected by ${ }^{19} \mathrm{~F}$ MRI. It has been reported that residual PDF localization in the eye following vitreoretinal surgery can be imaged by ${ }^{19} \mathrm{~F}$ MRI (69). The uptake and accumulation of the general anesthetic isoflurane, which bears 5 fluorine atoms, was measured in vivo in mice by ${ }^{19} \mathrm{~F}$ MRI (70). Lastly, the fluorinated antifungal agent voriconazole has been quantified in the brain using ${ }^{19} \mathrm{~F}$ MRI and tracking of voriconazole in patients has been reported (71).

${ }^{19} \mathrm{~F}$ MRI, among other MRI techniques, enables drug delivery monitoring, metabolism assessment, tracking of labeled cells, and the possibility of visualization of new fluorinated drug conjugates. Pharmacological research also shows that Magnetic Resonance Imaging can be applied to the discovery of metabolic drug pathways. The papers included in Table 2 are excellent examples of current studies in ${ }^{19} \mathrm{~F}$ MRI and ${ }^{19} \mathrm{~F}$ MRS of fluorinated drugs. ${ }^{19} \mathrm{~F}$ MRI is a preclinical imaging platform for non-invasive cell tracking, quantification of labeled cells that pro-

Table 2. Examples of fluorine-containing drugs that have been monitored by ${ }^{19} \mathrm{~F}$ MRI or ${ }^{19} \mathrm{~F}$ MRS.

\begin{tabular}{|c|c|c|c|}
\hline Reference & Monitored drug & $\begin{array}{c}\text { Method } \\
\left({ }^{19} \mathrm{~F} \mathrm{MRI} /{ }^{19} \mathrm{~F} \mathrm{MRS}\right)\end{array}$ & Application \\
\hline$(57)$ & 5-fluorouracil & ${ }^{19} \mathrm{~F} \mathrm{MRI}$ & $\begin{array}{l}\text { Solid tumors including colon, rectal, breast, } \\
\text { gastric, pancreatic, ovarian, bladder, and liver cancer }\end{array}$ \\
\hline$(58)$ & 5-fluorouracil & ${ }^{19} \mathrm{~F}$ MRS & \\
\hline$(59)$ & 5-fluorocytosine & ${ }^{19} \mathrm{~F} \mathrm{MRS}$ & Antifungal agent \\
\hline$(60)$ & 3'-fluoromethotrexate & ${ }^{19} \mathrm{~F} \mathrm{MRS}$ & $\begin{array}{c}\text { Fluorinated analog of methotrexate, a chemotheraputic and } \\
\text { immunosupressant }\end{array}$ \\
\hline$(61)$ & Capecitabine & ${ }^{19} \mathrm{~F} \mathrm{MRS}$ & breast, gastric, and colorectal cancer \\
\hline$(62)$ & Fluphenazine & ${ }^{19} \mathrm{~F}$ MRI & Antipsychotic \\
\hline$(63)$ & Fluoxetine & ${ }^{19} \mathrm{~F} \mathrm{MRS}$ & Antidepressant \\
\hline$(64)$ & Fluvoxamine & ${ }^{19} \mathrm{~F} \mathrm{MRS}$ & Antidepressant \\
\hline$(65)$ & Fluorodopa & ${ }^{19} \mathrm{~F} \mathrm{MRI}$ & Dopaminergic receptor probe \\
\hline (66) & Niflumic acid & ${ }^{19} \mathrm{~F}$ MRS & Cyclooxygenase- 2 inhibitor \\
\hline$(67)$ & Flurbiprofen & ${ }^{19} \mathrm{~F} \mathrm{MRS}$ & Anti-inflammatory \\
\hline$(68)$ & Dexfenfluramine & ${ }^{19} \mathrm{~F}$ MRS & Serotonergic anorectic drug \\
\hline$(69)$ & Perfluorodecalin & ${ }^{19} \mathrm{~F} \mathrm{MRI}$ & $\begin{array}{c}\text { Used for increasing dissolved oxygen levels in } \\
\text { surgical procedures }\end{array}$ \\
\hline (70) & Isoflurane & ${ }^{19} \mathrm{~F} \mathrm{MRI}$ & General anesthetic \\
\hline$(71)$ & Voriconazole & ${ }^{19} \mathrm{~F}$ MRS & Antifungal agent \\
\hline
\end{tabular}




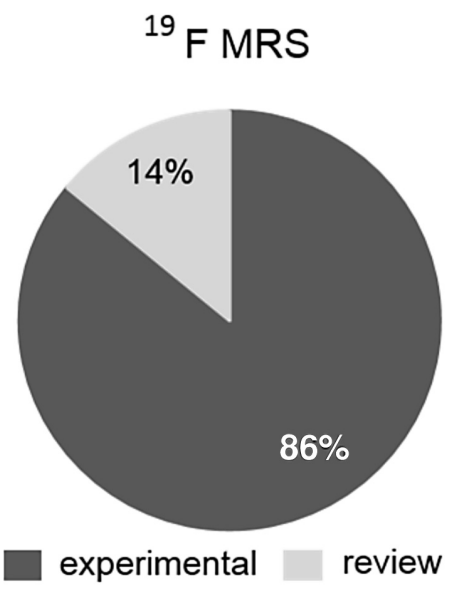

Figure 1. Number of publications discussed ${ }^{19} \mathrm{~F}$ MRS in vitro classified for experimental and review work. Data 1985-2019 collected from the Library of National Center for Biotechnology Information (NCBI) PubMed Data Base.

vides image contrast better then paramagnetic agents (iron or gadolinium particles) and conventional ${ }^{1} \mathrm{H}$ MRI (Figure 1).

The number of papers reporting ${ }^{19} \mathrm{~F}$ MRI applications in clinics and research published during 1985-2019 has increased. Figure 2 represents the data collected using the PubMed database (US National Library of Medicine National Institutes of Health).

\section{CONCLUSION}

As the fluorine nuclei are normally absent in proteins, there is no natural abundance background signal. Therefore, any simple method allowing for the identification of ${ }^{19} \mathrm{~F}$ compounds and to determine their concentrations is potentially useful in cancer diagnosis and treatments. Monitoring drugs is a key step in the use of new targeted therapies for breast cancer. Research in three-dimensional cell cultures will directly influence the development of in vivo studies. In addition, careful analysis of the samples prepared and the development of a new research methodology and new contrast media will improve diagnostic efficacy in this direction. A combination of targeted therapy and early detection of cancer can lead to new drug synthesis and more effective detection.

\section{Acknowledgments}

Dorota Bartusik-Aebisher acknowledges support from the National Center of Science NCN (New

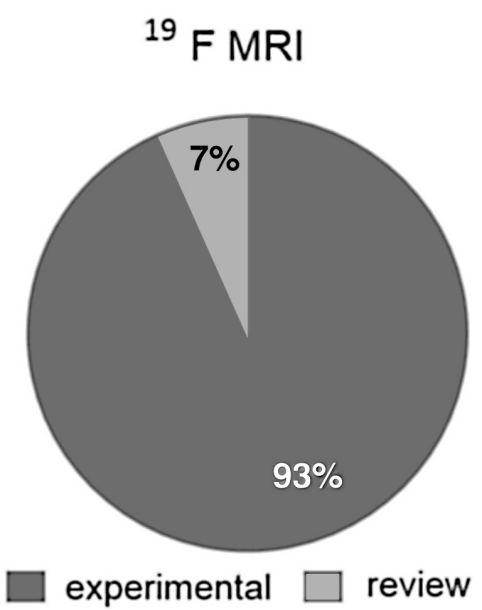

Figure 2. Number of publications of ${ }^{19} \mathrm{~F}$ MRI classified for experimental and review work. Data 1985-2019 collected from the Library of National Center for Biotechnology Information (NCBI) PubMed Data Base.

drug delivery systems-MRI study, Grant OPUS-13 number 2017/25/B/ST4/02481).

\section{Conflict of interests}

The authors declare no conflict of interest.

\section{REFERENCES}

1. Ruiz-Cabello J., Barnett B.P., Bottomley P.A., Bulte J.W.: NMR Biomed. 24, 114 (2011).

2. Kauppinen R.A., Peet A.C.: Cancer Biol. Ther. 12, 665 (2011).

3. Zemtov A., Dixon L.: Arch. Dermatol. 129, 215 (1993).

4. Harry V.N., Deans H., Ramage E., Parkin D.E., Gilbert F.J.: Int. J. Gynecol. Cancer. 19, 186 (2009).

5. Liu B., Ramalho M., AlObaidy M., Busireddy K.K., Altun E., et al.: World J. Radiol. 6, 544 (2014).

6. Ladd M.E., Bachert P., Meyerspeer M., Moser E., Nagel A.M., et al.: Prog. Nucl. Magn. Reson. Spectrosc. 109, 1 (2018).

7. Bottomley P.A., Hardy C.J., Argersinger R.E., Allen-Moore G.: Med. Phys. 14, 1 (1987).

8. Santhana Mariappan S.V., Subramanian S., Chandrakumar N., Rajalakshmi K.R., Sukumaran S.S.: Magn. Reson. Med. 8, 119 (1988).

9. Hequet E., Henoumont C., Muller R.N., Laurent S.: Future Med. Chem. 1157 (2019).

10. Neubauer A.M., Myerson J.., Caruthers S.D., Hockett F.D., Winter P.M., et al.: Magn. Reson. Med. 60,1066 (2008). 
11. Zhou Z.X., Zhang B.G., Zhang H., Huang X.Z., Hu Y.L., et al.: Acta Pharmacol. Sin. 30, 577 (2009).

12. Kadayakkara D.K., Janjic J.M., Pusateri L.K., Young W.B., Ahrens E.T.: Magn. Reson. Med. 64, 1252 (2010).

13. Hahn T., Kozerke S., Schwizer W., Fried M., Boesiger P., et al.: Magn. Reson. Med. 66, 812 (2011).

14. Boehm-Sturm P., Mengler L., Wecker S., Hoehn M., Kallur T.: PLoS One 6, e29040 (2011).

15. Weise G., Basse-Lüsebrink T.C., Kleinschnitz C., Kampf T., Jakob P.M., et al.: PLoS One 6, e28143 (2011).

16. Hahn T., Kozerke S., Schwizer W., Fried M., Boesiger P., et al.: Radiology 265, 917 (2012).

17. Giraudeau C., Djemad' B., Ghaly M.A., Boumezbeur F., Mériaux S., et al.: NMR Biomed. 25, 654 (2012).

18. Waiczies H., Guenther M., Skodowski J., Lepore S., Pohlmann A., et al.: J. Vis. Exp. 50251 (2013).

19. Shi Y., Oeh J., Eastham-Anderson J., Yee S., Finkle D., et al.: Neoplasia 15, 1241 (2013).

20. Hertlein T., Sturm V., Jakob P., Ohlsen K.: PLoS One 8, e64440 (2013).

21. Zhong J., Sakaki M., Okada H., Ahrens E.T.: PLoS One 8, e59479 (2013).

22. Waiczies H., Lepore S., Drechsler S., Qadri F., Purfürst B., et al.: Sci. Rep. 3, 1280 (2013).

23. Patel S.K., Williams J., Janjic J.M.: Biosensors (Basel) 3, 341 (2013).

24. Giraudeau C., Geffroy F., Mériaux S., Boumezbeur F., Robert P., et al.: Angiogenesis 16, 171 (2013).

25. Ahrens E.T., Helfer B.M., O'Hanlon C.F., Schirda C.: Magn. Reson. Med. 72, 1696 (2014).

26. Matsushita H., Mizukami S., Sugihara F., Nakanishi Y., Yoshioka Y., et al.: Angew. Chem. Int. Ed. Engl. 53, 1008 (2014).

27. Jacoby C., Temme S., Mayenfels F., Benoit N., Krafft M.P., et al.: NMR Biomed. 27, 261 (2014).

28. Temme S., Jacoby C., Ding Z., Bönner F., Borg N., et al.: J. Leukoc. Biol. 95, 689 (2014).

29. Muhammad G., Jablonska A., Rose L., Walczak P., Janowski M.: Acta Neurobiol. Exp. (Wars) 75, 144 (2015).

30. Nakamura T., Sugihara F., Matsushita H., Yoshioka Y., Mizukami S., et al.: Chem. Sci. 6, 1986 (2015).

31. Zhong J., Narsinh K., Morel P.A., Xu H., Ahrens E.T.: PLoS One 10, e0140238 (2015).
32. Gaudet J.M., Ribot E.J., Chen Y., Gilbert K.M., Foster P.J.: PLoS One 10, e0118544 (2015).

33. Gonzales C., Yoshihara H.A., Dilek N., Leignadier J., Irving M., et al.: PLoS One 11, e0164557 (2016).

34. Kenny G.D., Shaw K.P., Sivachelvam S., White A.J., Botnar R.M., et al:. J. Fluor. Chem. 184, 58 (2016).

35. Taylor A.J., Granwehr J., Lesbats C., Krupa J.L., Six J.S., et al.: PLoS One 11, e0163704 (2016).

36. Olaru A.M., Robertson T.B.R., Lewis J.S., Antony A., Iali W., et al.: ChemistryOpen 7, 97 (2017).

37. Constantinides C., Maguire M.L., Stork L., Swider E., Srinivas M., et al.: J. Magn. Reson. Imaging 45, 1659 (2017).

38. Liang S., Dresselaers T., Louchami K., Zhu C., Liu Y., et al.: NMR Biomed. 30, e3776 (2017).

39. Shin S.H., Park S.H., Kang S.H., Kim S.W., Kim M., et al.: Contrast Media Mol. Imaging 2017, 4896310 (2017).

40. van Heeswijk R.B., Colotti R., Darçot E., Delacoste J., Pellegrin M., et al.: Magn. Reson. Med. 79, 2724 (2018).

41. Khurana A., Chapelin F., Xu H.., Acevedo J.R., Molinolo A., et al.: Magn. Reson. Med. 79, 1972 (2018).

42. Christmann V., Rosenberg J., Seega J., Lehr C.M.: Pharm. Res. 14, 1066 (1997).

43. Langereis S., Keupp J., van Velthoven J.L., de Roos I.H., Burdinski D., et al.: J. Am. Chem. Soc. 131, 1380 (2009).

44. Peng H., Blakey I., Dargaville B., Rasoul F., Rose S., et al.: Biomacromolecules 10, 374 (2009).

45. Takaoka Y., Sakamoto T., Tsukiji S., Narazaki M., Matsuda T., et al.: Nat. Chem. 1, 557 (2009).

46. Srinivas M., Cruz L.J., Bonetto F., Heerschap A., Figdor C.G., et al.: Biomaterials 31, 7070 (2010).

47. Bartusik D., Tomanek B.: J. Pharm. Biomed. Anal. 51, 894 (2010).

48. Bartusik D., Tomanek B.: Arch. Biochem. Biophys. 493, 234 (2010).

49. Hitchens T.K., Ye Q., Eytan D.F., Janjic J.M., Ahrens E.T., et al.: Magn. Reson. Med. 65, 1144 (2011).

50. Bonetto F., Srinivas M., Heerschap A., Mailliard R., Ahrens E.T., et al.: Int. J. Cancer 129, 365 (2011).

51. Li X., Li H., Liu G., Deng Z., Wu S., et al.: Biomaterials 33, 3013 (2012). 
52. Helfer B., Balducci A., Sadeghi Z., Flask C., Wesa A.: Mol. Ther. 20, S192 (2012).

53. Diou O., Tsapis N., Giraudeau C., Valette J., Gueutin C., et al.: Biomaterials 33, 5593 (2012).

54. Stoll G., Basse-Lüsebrink T., Weise G., Jakob P.: Wiley Interdiscip. Rev. Nanomed. Nanobiotechnol. 4, 438 (2012).

55. Reid D., Murphy P.: Drug Discov. Today 13, 473 (2008).

56. Gillis E.P., Eastman K.J., Hill M.D., Donnelly D.J., Meanwell N.A.: J. Med. Chem. 58, 8315 (2015).

57. Brix G., Bellemann M.E., Haberkorn U., Gerlach L., Bachert P., et al.: Magn. Reson. Med. 34, 302 (1995).

58. Presant C.A., Wolf W., Albright M.J., Servis K.L., Ring R., et al.: J. Clin. Oncol. 8, 1868 (1990).

59. Hamstra D.A., Lee K.C., Tychewicz J.M., Schepkin V.D., Moffat B.A., et al.: Mol. Ther. 10, 916 (2004).

60. Spees W.M., Yang G., Veach D., Rubio M.B., Koutcher J.A., et al.: Mol. Cancer. Ther. 2, 933 (2003).

61. Klomp D., van Laarhoven H., Scheenen T., Kamm Y., Heerschap A.: NMR Biomed. 20, 485 (2007).

(C) 2020 by Polish Pharmaceutical Society. This is an open-access article under the CC BY NC license (c) () (9)
62. Arndt D.C., Ratner A.V., Faull K.F., Barchas J.D., Young S.W.: Psychiatry Res. 25, 73 (1988).

63. Bolo N.R., Hode Y., Nedelec J.F., Laine E., Wagner G., et al.: Neuropsychopharmacology 23, 428 (2000).

64. Strauss W.L., Layton M.E., Dager S.R.: Am. J. Psychiatry 155, 380 (1998).

65. Yanagisawa D., Oda K., Inden M., Morikawa S., Inubushi T., et al.: J. Neurosci. Res. 95, 1485 (2017).

66. Bilecen D., Schulte A.C., Kaspar A., Kustermann E., Seelig J., et al.: NMR Biomed. 16, 144 (2003).

67. Lee D.J., Burt C.T., Koch R.L.: J. Invest. Dermatol. 99, 431 (1992).

68. Christensen J.D., Yurgelun-Todd D.A., Babb S.M., Gruber S.A., Cohen B.M., et al.: Brain Res. 834, 1 (1999).

69. Noske W., Gewiese B., Schilling A., Stiller D., Wolf K.J., et al.: Ger. J. Ophthalmol. 2, 207 (1993).

70. Constantinides C., Maguire M.L., Stork L., Swider E., Srinivas M., et al. J. Magn. Reson. Imaging. 45, 1659 (2017).

71. Henry M.E., Bolo N.R., Zuo C.S., Villafuerte R.A., Cayetano K., et al.: Antimicrob. Agents Chemother. 57, 5271 (2013).

\footnotetext{
2020 by Polish Pharmaceutical Society. This is an open-access article under the
(http://creativecommons.org/licenses/by-nc/4.0/).
} 